Pak. j. sci. ind. res. Ser. B: biol. sci. 2017 60(1) 27-35

\title{
Development of Buckwheat Cookies Supplemented with Wheat Flour
}

\author{
Nisar Hussain ${ }^{a *}$, Javid Ullaha, EhsanElahi ${ }^{\mathrm{b}}$, Sajjad Ahmad ${ }^{\mathrm{a}}$, Muhammad Zakaria ${ }^{\mathrm{a}}$, \\ Murtaza $^{a}$, Saeed Ahmed ${ }^{c}$, Nazeer Ahmed ${ }^{d}$ and Zelle Huma ${ }^{e}$ \\ ${ }^{a}$ Department of Food Science and Technology, Faculty of Nutrition Science, \\ PCSIR Laboratory, Skardu, Pakistan \\ ${ }^{b}$ Environment and Natural Resource Management, National Rural Support Programme (NRSP), \\ Islamabad, Pakistan \\ ${ }^{\circ}$ Centre of Agriculture Sciences, State University of Londrina, Londrina, Parana (PR), Brazil \\ ${ }^{d}$ Key Laboratory of Applied Entomology, Northwest A\&F University, Yangling, Shaanxi-712100, China \\ ${ }^{\mathrm{e}}$ Department of Plant Protection, University of Agriculture, Peshawar, Pakistan
}

(received February 15, 2016; revised September 4, 2016; accepted September 9, 2016)

\begin{abstract}
The present study was conducted to develop buckwheat cookies supplemented with wheat flour. Buckwheat and wheat flour were examined for their proximate composition. Buckwheat flour contained $11.6 \%$ moisture, $15.79 \%$ crude protein, $1.81 \%$ crude fat, $1.83 \%$ ash, $0.70 \%$ crude fibre content and $68.27 \%$ NFE, while wheat flour contained moisture content $13.12 \%$, crude fibre content $1.93 \%$, crude fat $1.42 \%$, crude protein content $12.53 \%$, ash content $1.57 \%$ and $69.43 \%$ NFE, respectively. Wheat flour was incorporated into buckwheat flour at 10,20,30, 40 and 50\% ratio to make composite flour and the developed cookies were analysed for quality evaluation. Supplementation of wheat flour significantly influenced the proximate and mineral composition of buckwheat flour based cookies. Moisture contents, crude fibre contents and NFE (Nitrogen Free Extract) increased, whereas crude fat, crude protein and ash contents decreased. Mineral contents (Fe, Ca, K, $\mathrm{Zn}$ and $\mathrm{Mg}$ ) of developed buckwheat cookies decreased with increase in wheat flour supplementation levels. Sensory characteristics of supplemented cookies increased with increase in supplementation levels of wheat flour and were acceptable by judges in terms of test, colour, texture and overall acceptability. Cookies developed from $\mathrm{C} 50 \% \mathrm{C}$ supplementation level of wheat flour got maximum scored points while $\mathrm{C}_{0}$ control $\mathrm{C}_{0}$ was found to be more nutritious and gluten free having more crude protein and mineral contents when compared to supplemented cookies.
\end{abstract}

Keywords: buckwheat cookies, chemical quality, sensory quality, wheat flour

\section{Introduction}

Cookies and biscuits are very vital bakery products. Both are liked and eaten by all age groups especially school going kids who need more energy like proteins per unit body weight when compared to adults (Shahzad et al., 2006). These are ideal for availability of essential nutrients. The term cookies comes from the Dutch word koekje (little cake) and the name biscuit is the Latin word which means biscoctum (Macrae et al., 1993). Cookies and biscuits are different from other bakery items such as cakes and bread because these contain lower moisture contents as compared to other bakery foods and are relatively free from microbial spoilage and have longer shelf life (Wade, 1988). Cookies are prepared by supplementing different low priced sources like pulses and legumes flour with wheat flour (Akubor and Onimawo, 2003). In supplementation, proteins

\footnotetext{
*Author for correspondence; E-mail: Nisarskd14@gmail.com
}

giving constituent for biscuits should have sweet flavour, high protein efficiency ratio and low water absorption capacity. It should neither have negative influence on the dough spread ratio and texture nor cause any significant changes in the consistency of dough (Lorenz, 1983). The challenge of selecting the best-suited protein source has made the baking factory to examine such components that assign desirable functional and nutritional characteristics to the baked items (Tyagi et al., 2007). Common buckwheat Fagopyrum esculentum Moench (sweet buckwheat) is a broad leafy herbaceous crop that belongs to the family Polygonaceae. Its seeds structurally and chemically resemble that of wheat grains; therefore, it is considered as pseudo cereal. It originated from East Asia and then shifted into European countries in the $15^{\text {th }}$ century. The cultivation of this miracle crop has spread to many other countries of the world such as The United States of America, Canada, China, Latin America and Africa, with an 
annual production of about one million tonnes (Eggum et al., 1980; Pomeranz and Robbins, 1972).

There are various species of buckwheat grown throughout the world, but only nine of them have nutritional and agricultural value (Krkoskova and Mrazova, 2005). Mostly, two types of buckwheat (Common buckwheat and Tartary buckwheat) are used as a source of food throughout the world. These two species of buckwheat are cultivated in mountainous regions of Pakistan, mostly in Gilgit-Baltistan at the area of 948 hectares with an annual production of 1798 metric tonnes (SSR, 2007). Because of high nutritional and medicinal value, its production has been increased in recent years. Being gluten free, it has medicinal value and is used in gluten free food preparation for those who have gluten allergy (celiac patients) (Bonafaccia et al., 2003). It is naturally gluten free and contains various kinds of essential nutrients including easily digestible protein, starch, essential minerals ( $\mathrm{Zn}, \mathrm{Fe}, \mathrm{K}, \mathrm{Ca}, \mathrm{Mg}, \mathrm{Mn}$, and $\mathrm{Cu}$ ), amino acids (lysine) and rutin. It is low in saturated fat, sodium, and cholesterol (Bonafaccia et al., 2003). Common buckwheat that is mostly consumed can be compared to other species because it is sweet in taste and easy to dehul unlike tartary buckwheat that has bitter taste and is small in seed size with tough seed coating hence, it is hard to dehull (Jiang et al., 2007). Buckwheat is an excellent source of micronutrients like potassium, manganese, copper, iron, and zinc (Ikeda and Yamashita, 1994). In contrast with cereals, buckwheat contained more crude protein, high in lysine content and gluten free that makes it important from medicinal and nutritional viewpoint. Therefore, it is used to prepare an alternate gluten free food for celiac patients (Javornik and Kreft, 1984; Eggum, 1980). Buckwheat foodstuffs are considered as a good nutritional and medicinal value food (Bonafaccia and Kreft, 1998; Mazza, 1989). It has been reported that there is high concentration of amino acid in buckwheat (Kato et al., 2001; Liu et al., 2001).

Present experiment was therefore conducted to develope buckwheat cookies supplemented with wheat flour to determine the level of buckwheat and to evaluate the gluten free biscuits for patients.

\section{Materials and Methods}

The present research work was carried out at (PCSIR) Pakistan Council of Scientific and Industrial Research Laboratories, Skardu during 2012-2013.
Collection of raw materials. Common buckwheat (sweet) Fagopyrum esculentum and wheat flour were selected for the development of buckwheat cookies. Whole buckwheat was procured from District Ghancha Baltistan while wheat flour, sugar, industrial fat and other ingredients used in cookies preparation were purchased from local market and brought to PCSIR (Pakistan Council of Scientific and Industrial Research) Laboratory, Skardu. Dehulling and milling of buck wheat was conducted to obtain flour. The hulls were removed through blower to obtain dehulled buckwheat. The dehulled grains were milled by using laboratory mill. The flour was sealed in polyethylene bags and stored in refrigerator for further use.

Preparation of buckwheat cookies. according to the official method of AACC (2000) different \% level (10, $20,30,40$, and 50) of wheat flour were prepared for buckwheat. The recipe used to prepare buckwheat cookies is shown in Table 1.

Proximate composition. Proximate composition includes moisture, crude protein, crude fat, crude fibre, ash and nitrogen free extract. Moisture occurred by oven dehydration method at $105^{\circ} \mathrm{C}$ up to constant weight. Crude protein was evaluated by using Kjeldhal method and crude fat extracted by ether extraction method using Soxhlet apparatus. Crude fibre was known through acid digestion and alkali digestion method. Ash content was determined in muffle furnace at $550{ }^{\circ} \mathrm{C}$ for $6 \mathrm{~h}$. For all these determinations powdered and oven dried samples were used in triplicate in accordance with standard procedures. NFE was calculated by difference (AACC, 2000).

Mineral estimation. The developed buckwheat cookies were analysed for minerals ( $\mathrm{Ca}, \mathrm{Fe}, \mathrm{Zn}, \mathrm{K}$ and $\mathrm{Mg}$ ) through wet digestion. Iron, calcium, magnesium and zinc contents were calculated by using atomic absorption spectrophotometer, while potassium was estimated by

Table 1. Ingredients used in cookies preparation

\begin{tabular}{ll}
\hline \hline Ingredients & $\begin{array}{l}\text { Weight } \\
(\mathrm{g})\end{array}$ \\
\hline Flour & 500 \\
Sugar & 250 \\
Industrial fat & 250 \\
Baking powder & 6.50 \\
Salt & 0.040 \\
Egg & 1 \\
\hline \hline
\end{tabular}


the use of flame photometer; according to the recommended method of AACC (2000).

Minerals (Fe, $\mathrm{Zn}, \mathrm{Ca}$ and $\mathrm{Mn}$ ) were calculated in cookies. About $1 \mathrm{~g}$ of finely ground sample was kept in digestion tube and $10 \mathrm{~mL}$ concentrated nitric acid was added and kept at room temperature overnight. Then the mixture was treated with $4 \mathrm{~mL}$ concentrated perchloric acid and sample was kept on magnetic hot plate for digestion. The process was completed in about 1-2 h. The sample was then allowed to cool down to room temperature, transferred to $200 \mathrm{~mL}$ volume flask and filtered by using filter paper. The volume of sample in flask was made up to $100 \mathrm{~mL}$ with distilled water and absorbance was estimated through atomic absorption spectrophotometer (Model GBC 932 PLUS, UK).

Sensory evaluation. Supplemented buckwheat cookies were sensory evaluated in terms of taste, colour, texture and overall acceptability by presenting developed cookies to a panel of six judges using 9 points hedonic scale as recommended by Larmond (1977).

Statistical analysis. The data achieved from different treatments were statistically evaluated in MSTAT-C software using completely randomized design (CRD) and least significant difference (LSD) test (at 5\% level of significance) to separate means according to the method described by Steel and Torrie (1997).

\section{Results and Discussion}

The product was prepared using different ratios of ingredients in different trials. The samples were analysed for their proximate (crude fat, ash, crude fibre, crude protein, moisture and NFE (nitrogen free extract) contents and mineral composition (iron, zinc, magnesium, calcium and potassium). The developed buckwheat cookies were presented to a panel of six expert judges for estimation of organoleptic characteristics according to 9 point hedonic scale.

Proximate composition of buckwheat flour and wheat flour. Buckwheat (common buckwheat) flour and wheat flour used in the present research work were investigated for their chemical composition. Percentage chemical compositions are presented in Table 2.

The data shows that buckwheat flour contained $11.6 \%$ moisture, $15.79 \%$ crude protein, $1.81 \%$ crude fat, $1.83 \%$ ash, $0.70 \%$ crude fibre content and $68.27 \%$ NFE. These results are in close conformity with the outcomes of Bonafaccia et al. (2003), who confirmed that buckwheat
Table 2. Proximate composition of buckwheat flour and wheat flour

\begin{tabular}{|c|c|c|c|c|c|c|}
\hline $\begin{array}{l}\text { Sample } \\
\text { type }\end{array}$ & Moisture & $\begin{array}{l}\text { Crude } \\
\text { protein }\end{array}$ & $\begin{array}{l}\text { Crude } \\
\text { fat }\end{array}$ & $\begin{array}{l}\text { Crude } \\
\text { fibre }\end{array}$ & Ash & NFE \\
\hline \multicolumn{7}{|c|}{$\%$} \\
\hline $\begin{array}{l}\text { Buck- } \\
\text { wheat } \\
\text { flour }\end{array}$ & 11.60 & 15.79 & 1.81 & 0.70 & 1.83 & 68.27 \\
\hline $\begin{array}{l}\text { Wheat } \\
\text { flour }\end{array}$ & 13.12 & 12.53 & 1.42 & 1.93 & 1.57 & 69.43 \\
\hline
\end{tabular}

$\mathrm{NFE}=$ nitrogen free extract.

flour contained 7.89 to $10 \%$ moisture, 10.23 to $17 \%$ crude protein, 1.3 to $2.8 \%$ ash, 1.1 to $3.5 \%$ crude fat, 0.7 to $1.8 \%$ crude fibre and 64 to $73 \%$ NFE (Bilgicli, 2009; Fessas et al. 2008). Buckwheat flour contained 8.5 to $19 \%$ of crude protein content depending on the variety, fertilizer and pesticides used that probably affect the overall concentration of buckwheat protein contents (Fornal, 1999). Data shows that wheat flour contained $13.12 \%$ moisture, $12.53 \%$ crude protein, $1.42 \%$ crude fat, $1.93 \%$ crude fibre, $1.57 \%$ ash content and NFE $69.43 \%$. These outcomes are in close agreement with the study of Wahab (2001), who reported that wheat flour contain $7.38 \%$ moisture, $10.40 \%$ protein, $2.15 \%$ crud fat, $2.80 \%$ crude fibre, $1.47 \%$ ash and $75.80 \%$ NFE. Similar result are also reported in the outcomes of Ahmad et al. (2005) who examined that commercially available flour contained 9.95-11.58\% moisture, 0.52$0.68 \%$, ash, $0.94-1.51 \%$ fat, $10.32-11.58 \%$ protein, $0.40-0.60 \%$ crude fibre and $74.62-77.74 \%$ NFE.

Proximate composition of different treatments of developed buckwheat cookies. The products prepared with different formulations were analysed for proximate composition. The data is shown in Table 3.

Moisture content. Analysis of variance showed that supplementation with wheat flour had significant effect on moisture content of common buckwheat flour based cookies. Data reveals that moisture content of supplemented buckwheat cookies increased with increase incorporation of wheat flour. High moisture content of supplemented cookies may be credited to high moisture content of wheat flour in contrast to buckwheat flour. This may be due to relatively higher amount of fibre content in wheat flour than that of common buckwheat flour. The results achieved are in complete confirmation with the finding of Eastwood (1986), who reported that 
Table 3. Proximate composition of different treatments of developed buckwheat cookies

\begin{tabular}{lllllll}
\hline \hline $\begin{array}{l}\text { Treat- } \\
\text { ments }\end{array}$ & $\begin{array}{l}\text { Mois- } \\
\text { ture }\end{array}$ & $\begin{array}{l}\text { Crude } \\
\text { fat }\end{array}$ & $\begin{array}{l}\text { Crude } \\
\text { fibre }\end{array}$ & $\begin{array}{l}\text { Crude } \\
\text { protein }\end{array}$ & $\begin{array}{l}\text { Ash } \\
\text { content }\end{array}$ & NFE \\
\hline $\mathrm{C}_{0}$ & $2.88^{\mathrm{d}}$ & $24.44^{\mathrm{a}}$ & $0.72^{\mathrm{e}}$ & $15.87^{\mathrm{a}}$ & $1.70^{\mathrm{a}}$ & $54.39^{\mathrm{f}}$ \\
$\mathrm{C}_{1}$ & $3.08^{\mathrm{c}}$ & $24.24^{\mathrm{b}}$ & $0.88^{\mathrm{d}}$ & $15.31^{\mathrm{b}}$ & $1.59^{\mathrm{ab}}$ & $54.91^{\mathrm{e}}$ \\
$\mathrm{C}_{2}$ & $3.16^{\mathrm{bc}}$ & $24.10^{\mathrm{bc}}$ & $1.01^{\mathrm{c}}$ & $14.99^{\mathrm{c}}$ & $1.50^{\mathrm{b}}$ & $55.24^{\mathrm{d}}$ \\
$\mathrm{C}_{3}$ & $3.27^{\mathrm{b}}$ & $23.96^{\mathrm{c}}$ & $1.16^{\mathrm{b}}$ & $14.67^{\mathrm{d}}$ & $1.33^{\mathrm{c}}$ & $55.61^{\mathrm{c}}$ \\
$\mathrm{C}_{4}$ & $3.42^{\mathrm{a}}$ & $23.79^{\mathrm{d}}$ & $1.29^{\mathrm{a}}$ & $14.37^{\mathrm{e}}$ & $1.05^{\mathrm{d}}$ & $56.08^{\mathrm{b}}$ \\
$\mathrm{C}_{5}$ & $3.50^{\mathrm{a}}$ & $23.68^{\mathrm{d}}$ & $1.35^{\mathrm{a}}$ & $13.93^{\mathrm{f}}$ & $0.95^{\mathrm{d}}$ & $56.59^{\mathrm{a}}$ \\
\hline \hline
\end{tabular}

$\mathrm{C}_{0}=$ Control $100 \%$ common buckwheat flour; $\mathrm{C}_{1}=90 \%$ buckwheat $+10 \%$ wheat flour; $\mathrm{C}_{2}=80 \%$ buckwheat $+20 \%$ wheat flour; $\mathrm{C}_{3}=70 \%$ buckwheat $+30 \%$ wheat flour; $\mathrm{C}_{4}=$ $60 \%$ buckwheat $+40 \%$ wheat flour; $\mathrm{C}_{5}=50 \%$ buckwheat + $50 \%$ wheat flour; $\mathrm{NFE}=$ nitrogen free extract.

the incorporation of rice bran and wheat in bakery products preparation retain more moisture in developed products because of the existence of cellulose and hemicellulose. Other researchers (Pflaumer et al., 1990; French and Hill, 1988) also reported that the incorporation of guar gum and CMC hold more moisture amount in baked products because of their high water holding capacity.

Crude protein content. Significant differences were examined in protein content of buckwheat flour based cookies. Data indicates that protein content of wheat flour supplemented buckwheat cookies decreased with increase in wheat flour incorporation. The mean crude protein content results of test cookies were $\mathrm{C}_{0}(15.87 \%)$, $\mathrm{C}_{1}(15.30 \%), \mathrm{C}_{2}(14.99 \%), \mathrm{C}_{3}(14.67 \%), \mathrm{C}_{4}(14.37 \%)$ and $\mathrm{C}_{5}(13.93 \%)$. The highest mean value $(15.87 \%)$ was recorded in $\mathrm{C}_{0}$, while lowest mean value (13.93\%) in $\mathrm{C}_{5}$ (Table 3). High protein content of supplemented cookies may be credited to high protein content of common buckwheat flour contrasted to wheat flour. The outcomes achieved are in confirmation with the results of Baljeet et al. (2010) who reported a decrease in crude protein content with increase in a mixture of different flours from cereal, legume, or root crops that is created to satisfy specific functional characteristics and nutrient composition. This work also supported the finding of Dhingra and Jood (2001) who reported a decrease in the crude protein.

Crude fat content. Supplementation of wheat flour significantly influenced the crude fat content of common buckwheat flour based cookies. Data explained that crude fat content of wheat flour supplemented buckwheat cookies decreased with gradual increase in wheat flour incorporation. The mean crude fat content results of test cookies were (24.44\%), $\mathrm{C}_{1}(24.24 \%), \mathrm{C}_{2}(24.08 \%)$, $\mathrm{C}_{3}(23.96 \%), \mathrm{C}_{4}(23.79 \%)$ and $\mathrm{C}_{5}(23.68 \%)$. The highest mean value (24.44\%) was recorded in $\mathrm{C}_{0}$, while lowest mean value $(23.68 \%)$ in $\mathrm{C}_{5}$ (Table 3 ). Higher crude fat content may be credited to high crude fat content of wheat flour contrasted to buckwheat flour. The outcomes of the study are in agreement with the results of Khan et al. (2012) who estimated decreasing fat contents in gluten free ready to serve buckwheat product $(1.01 \%)$, $(0.71 \%),(0.59 \%),(0.59 \%)$ and $(0.34 \%)$. It is clear that by the addition of buckwheat flour, fat contents also increased.

Crude fibre content. Supplementation of wheat flour significantly affected the crude fibre content of common buckwheat flour based cookies. It is found from the results that crude fibre content of wheat flour supplemented buckwheat cookies increased with gradual increase in wheat flour incorporation. The mean crude fibre content results of test cookies were $\mathrm{C}_{0}(0.72 \%)$, $\mathrm{C}_{1}(0.88 \%), \mathrm{C}_{2}(1.01 \%), \mathrm{C}_{3}(1.16 \%), \mathrm{C}_{4}(1.29 \%)$ and $\mathrm{C}_{5}(1.35 \%)$. The highest mean value $(1.35 \%)$ was recorded in $\mathrm{C}_{5}$, while lowest mean value $(0.72 \%)$ in $\mathrm{C}_{0}$ (Table 3). High crude fibre content of supplemented biscuits may be credited to higher crude fibre in wheat flour in contrast to buckwheat flour. The present data achieved are in complete confirmation with the findings of Baljeet et al. (2010), who observed that incorporation of buckwheat flour had significant effect on crude fibre content. Hooda and Jood (2005) reported similar result on increase in dietary fibre with $10 \%$ replacement of wheat flour with fenugreek flour. Our findings also agree with the study of Hamid and Luan (2000) and French and Hill (1988), who found that incorporation of CMC in baked biscuits had significant effect.

Ash content. Supplementation of wheat flour significantly affects the ash content of common buckwheat flour based cookies. From the result it is found that ash content of buckwheat cookies decreased with gradual increase in wheat flour incorporation. The mean ash content results of test buckwheat cookies were $\mathrm{C}_{0}$ (1.70\%), $\mathrm{C}_{1}(1.59 \%), \mathrm{C}_{2}(1.50 \%), \mathrm{C}_{3}(1.33 \%), \mathrm{C}_{4}(1.05 \%)$ and $\mathrm{C}_{5}(0.95 \%)$. The highest mean value $(1.70 \%)$ was recorded in $\mathrm{C}_{0}$, whereas lowest mean value was found in $\mathrm{C}_{5}(0.95 \%)$ as shown in Table 3 . Decrease in ash content of supplemented buckwheat cookies with the increase in incorporation level of wheat flour is evidently due to the presence of higher ash content in buckwheat flour when compared to wheat flour. The outcomes 
achieved are contrary to the finding of Rani et al. (2008), where the addition of soya bean flour resulted in increased ash content in biscuits developed from wheat flour. Ndife et al. (2011), also points out an increase in ash content in whole wheat flour based bread with increase in different supplementation levels of soybean flour. These are contrary to the findings of the present studies.

Nitrogen free extract (NFE). Supplementation of wheat flour had significant effect on nitrogen free extract contents of common buckwheat flour based cookies. The findings shows that carbohydrate content of buckwheat cookies increased with gradual increase in wheat flour incorporation. The mean carbohydrate content of test cookies were $\mathrm{C}_{0}(54.39 \%), \mathrm{C}_{1}(54.91 \%)$, $\mathrm{C}_{2}(55.24 \%), \mathrm{C}_{3}(55.61 \%), \mathrm{C}_{4}(56.08 \%)$ and $\mathrm{C}_{5}(56.59 \%)$. The highest mean value $(56.59 \%)$ was observed in $\mathrm{C}_{5}$, while lowest mean value was found in $\mathrm{C}_{0}(54.39 \%)$ as shown in Table 3. Increase in nitrogen free extract (NFE) was observed when the supplementation with wheat flour increased. It might be due to the fact that common buckwheat contains higher crude protein content, ash content and crude fat than that of wheat flour, thus as the supplementation level of common buckwheat decreased, NFE increased. The results achieved are in complete confirmation with the results of Balajeet et al. (2010), reporting increase in the NFE content by the addition of buckwheat in wheat supplemented flour.

Mineral composition of different treatments of developed buckwheat cookies. The products prepared with different supplementation levels of wheat flour were analysed for proximate mineral composition. The data is shown in Table 4.

Table 4. Mineral composition of different treatments of developed buckwheat cookies

\begin{tabular}{llllll}
\hline \hline \multirow{2}{*}{$\begin{array}{l}\text { Treat- } \\
\text { ments }\end{array}$} & Iron & Zinc & Calcium & Potassium & Magnesium \\
\cline { 2 - 6 } & \multicolumn{5}{c}{$(\mathrm{mg} / 100 \mathrm{~g})$} \\
\hline $\mathrm{C}_{0}$ & $20.35^{\mathrm{a}}$ & $3.36^{\mathrm{a}}$ & $50.89^{\mathrm{a}}$ & $695.33^{\mathrm{a}}$ & $368.33^{\mathrm{a}}$ \\
$\mathrm{C}_{1}$ & $18.65^{\mathrm{b}}$ & $3.25^{\mathrm{b}}$ & $48.19^{\mathrm{b}}$ & $661.67^{\mathrm{b}}$ & $347.67^{\mathrm{b}}$ \\
$\mathrm{C}_{2}$ & $17.20^{\mathrm{c}}$ & $3.15^{\mathrm{c}}$ & $46.70^{\mathrm{c}}$ & $634.33^{\mathrm{c}}$ & $337.00^{\mathrm{b}}$ \\
$\mathrm{C}_{3}$ & $15.77^{\mathrm{d}}$ & $3.09^{\mathrm{c}}$ & $44.95^{\mathrm{d}}$ & $593.67^{\mathrm{d}}$ & $315.00^{\mathrm{c}}$ \\
$\mathrm{C}_{4}$ & $14.02^{\mathrm{e}}$ & $2.97^{\mathrm{d}}$ & $44.27^{\mathrm{e}}$ & $564.00^{\mathrm{e}}$ & $300.33^{\mathrm{d}}$ \\
$\mathrm{C}_{5}$ & $12.27^{\mathrm{f}}$ & $2.94^{\mathrm{d}}$ & $43.77^{\mathrm{f}}$ & $535.67^{\mathrm{f}}$ & $281.33^{\mathrm{e}}$ \\
\hline \hline
\end{tabular}

$\overline{\mathrm{C}_{0}}=$ Control $100 \%$ common buckwheat flour; $\mathrm{C}_{1}=90 \%$ buckwheat $+10 \%$ wheat flour; $\mathrm{C}_{2}=80 \%$ buckwheat $+20 \%$ wheat flour; $\mathrm{C}_{3}=70 \%$ buckwheat $+30 \%$ wheat flour; $\mathrm{C}_{4}=$ $60 \%$ buckwheat $+40 \%$ wheat flour; $\mathrm{C}_{5}=50 \%$ buckwheat + $50 \%$ wheat flour.
Potassium content. Supplementation of wheat flour significantly effect potassium $(\mathrm{K})$ content of common buckwheat flour based cookies. Data disclosed that potassium content of wheat flour supplemented buckwheat cookies decreased with gradual increase of wheat flour incorporation. The mean potassium content results of test cookies were as $\mathrm{mg} / 100 \mathrm{~g} \mathrm{C}_{0}$ (695.33), $\mathrm{C}_{1}$ (661.67), $\mathrm{C}_{2}$ (634.33), $\mathrm{C}_{3}(593.67), \mathrm{C}_{4}(564.00)$ and $\mathrm{C}_{5}$ (535.67). The highest mean value $(695.33 \mathrm{mg} /$ $100 \mathrm{~g}$ ) was recorded in $\mathrm{C}_{0}$, while lowest mean value (535.67 mg/100 g) in $\mathrm{C}_{5}$ (Table 4). High potassium content of supplemented cookies may be credited to high potassium content of buckwheat flour contrasted to wheat buckwheat flour.

Calcium content. Supplementation of wheat flour significantly effect calcium $(\mathrm{Ca})$ content of common buckwheat flour based cookies. Results obtained showed that calcium content of wheat flour supplemented buckwheat cookies decreased with gradual increase of wheat flour incorporation. The mean calcium content results of test cookies were as $\mathrm{mg} / 100 \mathrm{~g} \mathrm{C}_{0}(50.89), \mathrm{C}_{1}$ (48.19), $\mathrm{C}_{2}$ (46.70), $\mathrm{C}_{3}$ (44.95), $\mathrm{C}_{4}$ (44.27) and $\mathrm{C}_{5}$ (43.77). The highest mean value $(50.89 \mathrm{mg} / 100 \mathrm{~g})$ was recorded in $\mathrm{C}_{0}$, while lowest mean value $(43.77 \mathrm{mg} / 100 \mathrm{~g})$ in $\mathrm{C}_{5}$ (Table 4). Decrease in calcium content of supplemented buckwheat cookies may be credited to high calcium content of buckwheat flour contrasted to wheat flour.

Iron content. Supplementation of wheat flour significantly effect iron ( $\mathrm{Fe}$ ) content of common buckwheat flour based cookies. Results showed that iron content of wheat flour supplemented buckwheat cookies decreased with gradual increase of wheat flour incorporation. The mean iron content results of test cookies were as $\mathrm{mg} / 100 \mathrm{~g} \mathrm{C}_{0}$ (20.35), $\mathrm{C}_{1}$ (18.65), $\mathrm{C}_{2}$ (17.20), $\mathrm{C}_{3}$ (15.77), $\mathrm{C}_{4}(14.02)$ and $\mathrm{C}_{5}$ (12.27). The highest mean value $(20.35 \mathrm{mg} / 100 \mathrm{~g})$ was recorded in $\mathrm{C}_{0}$, while lowest mean value (12.27 mg/100 g) in $\mathrm{C}_{5}$ (Table 4). High iron content of supplemented biscuits may be credited to high iron content of buckwheat flour contrasted to wheat flour. The end results achieved are in complete confirmation with the findings of Khan et al. (2012). Kashlan et al. (1991) also reported that during baking significant loss of most of minerals such as iron content was found when baked bread was compared to wheat flour.

Zinc content. Supplementation of wheat to common buckwheat flour based cookies had significant $(p<0.005)$ effect on zinc $(\mathrm{Zn})$ content. It was observed that zinc 
content decreased with gradual increase in wheat flour supplementation levels. The mean results of test cookies were as $\mathrm{mg} / 100 \mathrm{~g} \mathrm{C}_{0}$ (3.36), $\mathrm{C}_{1}$ (3.25), $\mathrm{C}_{2}$ (3.15), $\mathrm{C}_{3}$ (3.09), $\mathrm{C}_{4}$ (2.97) and $\mathrm{C}_{5}$ (2.94). The highest mean value $(3.36 \mathrm{mg} / 100 \mathrm{~g})$ was recorded in $\mathrm{C}_{0}$, while lowest mean value $\left(2.94 \mathrm{mg} / 100 \mathrm{~g}\right.$ ) was in $\mathrm{C}_{5}$ (Table 4). Khan et al. (2005) and Steadman et al. (2001) noticed increase in zinc contents with increase in the addition of buckwheat flour to wheat flour bur contrasting results are observed in the present study.

Magnesium content. Supplementation of wheat flour significantly affected magnesium $(\mathrm{Mg})$ content of common buckwheat flour based cookies. Results revealed that magnesium content of wheat flour supplemented buckwheat cookies decreased with gradual increase in wheat flour supplementation. The mean magnesium content of test cookies were as $\mathrm{mg} / 100 \mathrm{~g} \mathrm{C}_{0}$ (368.33), $\mathrm{C}_{1}$ (347.67), $\mathrm{C}_{2}$ (337.00), $\mathrm{C}_{3}(315.00), \mathrm{C}_{4}(300.33)$ and $\mathrm{C}_{5}$ (281.33). The highest mean value $(368.33 \mathrm{mg} / 100 \mathrm{~g})$ was recorded in $\mathrm{C}_{0}$, while lowest mean value was found (281.33 mg/100 g) in $\mathrm{C}_{5}$ (Table 4). High magnesium content of supplemented buckwheat cookies may be credited to high magnesium content of buckwheat flour contrasted to wheat flour. When the supplementation level of wheat flour increased and buckwheat concentration decreased then the magnesium contents in cookies also decreased. The results achieved are in complete confirmation with the finding of Khan et al. (2012); Ikeda et al. (2006) and DeFrancischi et al. (1994) who found increase in magnesium content of tartary buckwheat flour than in whole-wheat flour. In the present study decrease in magnesium content was recorded, probably because of the addition of wheat flour to common buckwheat flour.

Sensory/organoleptic evaluation of different treatments of developed buckwheat cookies. The results of sensory/organoleptic evaluation of all treatments of buckwheat cookies are presented in Table 5.

Taste. Supplementation of wheat flour has significant effect on quality score in terms of taste. The minimum scored point (5.26) was recorded in $\mathrm{C}_{0}$, while maximum point scored (7.54) recorded in $\mathrm{C}_{5}$ (Table 5). The data shows that with the increase in wheat flour and reduction in buckwheat flour content, taste of developed cookies improved. The results achieved are in close confirmation with the findings of Tyagi et al. (2007), who reported the same result when products of biscuit incorporated with mustard flour was evaluated. Eneche (1999) also estimated maximum sensory scores for taste and overall acceptability for the cookies developed from $65 \%$ millet flour incorporating with $35 \%$ pigeon pea flour.

Colour. Supplementation of wheat flour significantly effect on quality score in terms of colour of common buckwheat flour based cookies. Results showed that quality score of buckwheat cookies increased with gradual increase of wheat flour incorporation. The lowest scored point (5.11) was recorded in $\mathrm{C}_{0}$, while maximum point scored (8.15) recorded in $\mathrm{C}_{5}$ (Table 5). The data shows that with the increase in wheat flour supplementation levels and reduction in buckwheat flour content, colour of developed cookies improved. The results achieved are in close confirmation with the findings of Tyagi et al. (2007) who reported that maximum colour score of 7.70 was observed of biscuits containing $15 \%$ defatted mustard flour. Khouryieh et al. (2006) also reported highest score points for colour in noodles formulated with soy flour and whole eggs. Our findings are also similar with the findings of Singh et al. (2005), who indicated maximum score points for colour at $15 \%$ supplementation of green gram and bengal gram.

Texture. Supplementation of wheat flour significantly $(p<0.005)$ effect quality score in terms of texture of common buckwheat flour based cookies. From these results it was observed that with gradual increase of wheat flour incorporation the quality score of buckwheat cookies also increased. The maximum point score (7.84) was recorded in $\mathrm{C}_{5}$, while lowest point scored (5.41) recorded in $\mathrm{C}_{0}$ (Table 5). The results revealed that with the increase in wheat flour and reduction in buckwheat flour, content of developed cookies improved. The

Table 5. Colour, taste, texture and overall acceptability of different treatments of developed buckwheat cookies

\begin{tabular}{lllll}
\hline \hline Treatments & Colour & Taste & Texture & $\begin{array}{l}\text { Overall } \\
\text { acceptability }\end{array}$ \\
\hline $\mathrm{C}_{0}$ & $5.11^{\mathrm{f}}$ & $5.26^{\mathrm{e}}$ & $5.41^{\mathrm{d}}$ & $5.26^{\mathrm{f}}$ \\
$\mathrm{C}_{1}$ & $5.75^{\mathrm{e}}$ & $5.66^{\mathrm{e}}$ & $5.62^{\mathrm{d}}$ & $5.67^{\mathrm{e}}$ \\
$\mathrm{C}_{2}$ & $6.31^{\mathrm{d}}$ & $5.98^{\mathrm{d}}$ & $6.00^{\mathrm{c}}$ & $6.10^{\mathrm{d}}$ \\
$\mathrm{C}_{3}$ & $6.88^{\mathrm{c}}$ & $6.38^{\mathrm{c}}$ & $6.74^{\mathrm{b}}$ & $6.67^{\mathrm{c}}$ \\
$\mathrm{C}_{4}$ & $7.53^{\mathrm{b}}$ & $6.91^{\mathrm{b}}$ & $7.00^{\mathrm{b}}$ & $7.15^{\mathrm{b}}$ \\
$\mathrm{C}_{5}$ & $8.15^{\mathrm{a}}$ & $7.54^{\mathrm{a}}$ & $7.84^{\mathrm{a}}$ & $7.85^{\mathrm{a}}$ \\
\hline \hline
\end{tabular}

9-point hedonic scale (points: likeness/dislike); 9. Like extremely; 8 . Like very much; 7. Like moderately; 6. Like slightly; 5. Neither like nor dislike; 4. Dislike slightly; 3. Dislike moderately; 2. Dislike very much; 1. Dislike extrem. 
results achieved are in close confirmation with the finding of Tyagi et al. (2007) who reported same result when incorporation of biscuits with mustard flour was evaluated. Eneche (1999) also indicated maximum sensory score points for texture and overall acceptability for the biscuits developed from incorporation of $65 \%$ millet flour with $35 \%$ pigeon pea flour.

Overall acceptability. Supplementation of wheat flour significantly effect quality score in terms of overall acceptability of common buckwheat flour based cookies. Results showed that quality score of buckwheat cookies increased with gradual increase of wheat flour incorporation. The maximum point score (7.85) was received in $\mathrm{C}_{5}$, while lowest point scored (5.26) recorded in $\mathrm{C}_{0}$ (Table 5). From these results it is clear that with the increase in wheat flour and reduction in buckwheat flour content, overall acceptability of developed cookies improved. The results achieved are in close confirmation with the findings of Tyagi et al. (2007) who reported the same result when the end product of mustard flour incorporation into biscuits was evaluated. Singh et al. (1993) also observed maximum mean score points for overall acceptability at $30 \%$ incorporation level of soy flour.

\section{Conclusion}

It is concluded from this research work that supplementation of wheat flour with buckwheat flour could produce acceptable cookies having nutritional value. Supplementation of wheat flour significantly influenced the proximate and mineral composition of buckwheat flour based cookies. Moisture contents, crude fibre contents and NFE (nitrogen free extract) increased whereas crude fat contents, crude protein contents and ash content decreased. Mineral contents $(\mathrm{Fe}, \mathrm{Ca}, \mathrm{K}, \mathrm{Zn}$ and $\mathrm{Mg}$ ) of developed buckwheat cookies decreased with the increase in wheat flour supplementation levels. Sensory evaluation of buckwheat cookies in terms of colour, texture, test and overall acceptability increased with the increase in wheat flour supplementation levels. Buckwheat leaves are used as green tea in many countries of the world so it is recommended that research work be carried out on green tea. It is also recommended that other varieties of buckwheat grown in Pakistan be looked into for its utilization.

\section{References}

ASSR, 2007. Northern Areas Agricultural Statistics Survey Report, Fruit Production in Northern Areas.
Department of Agriculture, Northern Areas Pakistan. pp. 53-69.

Ahmad, I., Ahmad, N., Kausar, T., Ashraf, M. 2005. Effect of maltogenic amylase on the shelf life of bread. Pakistan Journal of Food Science, 15: 15-19.

Akubor, P.I., Onimawo, I.A. 2003. Functional properties and performance of soybean and maize flour blends in cookies. Plant Foods for Human Nutrition, 58: $1-12$.

AACC, 2000. Official Methods of Analysis, American Association of Cereal Chemists, W. Horwitz (ed), $17^{\text {th }}$ edition, Gaithersburg, MD, USA.

Baljeet, S.Y., Ritika, B.Y., Roshan, L.Y. 2010. Studies on functional properties and incorporation of buckwheat flour for biscuit making. International Journal of Food Research, 17: 1067-1076.

Bilgicli, N. 2009. Effect of buckwheat flour on chemical and functional properties of tarhana. Food Science and Technology, 42: 514-518.

Bonafaccia, L., Gambelli, N., Fabjan, N., Kreft, I. 2003. Trace elements in flour and bran from common and tartary buckwheat. Food Chemistry, 80: 9-15.

Bonafaccia, G., Kreft, I. 1998. Possibilities for the development of new products from minor cereals. In: Asian Food Product Development, H. Corke and R. Lin (eds), pp. 1-5, Science Press, Beijing, China.

DeFrancischi, M.L.P., Salgado, J.M., Leitao, R.F.F. 1994. Chemical, nutritional and technological characteristics of buckwheat and non-prolamine buckwheat flours in comparison of wheat flour. Plant Foods for Human Nutrition, 46: 323-329.

Dhingra, S., Jood, S. 2001. Organoleptic and nutritional evaluation of wheat breads supplemented with soybean and barley flour. Food Chemistry, 77: 479488.

Eastwood, M.A. 1986. Vegetable Fiber: its Physical Properties. Protein Nutrition Society, 32: 137.

Eggum, B.O., Kreft, I., Javornik, B. 1980. Chemical composition and protein quality of buckwheat. (Fagopyrum esculentum Moench). Plant Foods for Human Nutrition, 30: 175-179.

Eggum, B.O. 1980. The protein quality of buckwheat in comparison with other protein sources of plant and animal origin. In: Buckwheat Symposium Ljubljana, Sept. 1-3, pp. 115-120.

Eneche, E.H. 1999. Biscuit making potential of millet/ pigeonpea flour blends. Plant Foods for Human Nutrition, 54: 21-27.

Fessas, D., Signorelli, M., Pagaai, A., Mariotti, M., 
Jametti, S., Schirald, A. 2008. Guidelines for buckwheat enriched bread: Thermal analysis approach. Journal of Thermal Analytical and Calculation, 9: 9-10.

Fornal, L. 1999 Chemizmnasiongryki i kierunkispozy wczegowykorzystania. BiuletynNaukowy, 4: 7-17.

French, S.J., Hill, M.A. 1988. High fiber foods comparison of some baked products containing guar gum and pectin. Journal of Plant Foods, 6: 101-109.

Hamid, A.A., Luan, Y.S. 2000. Functional properties of dietary fiber prepared from defatted rice bran. Food Chemistry, 68: 15-19.

Hooda, S., Jood, S. 2005. Organoleptic and nutritional evaluation of wheat biscuits supplemented with untreated and treated fenugreek flour. Food Chemistry, 90: 427-435.

Ikeda, S., Yamashita, Y., Tomurai, K., Kreff, I. 2006. Nutritional comparison in mineral characteristics between buckwheat and cereals. Journal of Fagopyrum, 23: 61-65.

Ikeda, S., Yamashita, Y. 1994. Buckwheat as a dietary source of zinc, copper and manganese. Journal of Fagopyrum, 14: 29-34.

Jiang, P., Burczyn, F., Campbell, S.C., Pierce, G., Austria, A.J., Briggs, C. 2007. Rutin and flavonoid contents in three buckwheat species Fagopyrum esculentum, $F$. tataricum and F. homotropicum and their protective effects against lipid peroxidation. Food Research International, 40: 356-364.

Javornik, B., Kreft, I. 1984. Characterization of buckwheat proteins. Journal of Fagopyrum, 4: 30-38.

Kashlan, N.B., Srivastava, V.P., Muohanna, N.A., Motawa, Y.K., Mameesh, M.S. 1991. The proximate and elemental compositon of wheat flour and major types of bread consumed in Kuwait. Journal of Food Chemistry, 39: 205-210.

Kato, N., Kayashita, J., Tomotake, H. 2001. Nutritional and physiological functions of buckwheat protein. Recent Research Development Nutrition, 4: 113-119.

Khan, F., Zeb, A., Arif, M., Ullah, J., Wahab, S. 2012. Preparation and evaluation of gluten free ready to serve buckwheat product. Journal of Agricultural and Bio Sciences, 7: 633-637.

Khan, M.I., Anjum, F.M., Hussain, S., Tariq, T.M. 2005. Effect of soy flour supplementation on mineral and phytate content of unleavened flat bread (Chapatis). Nutrition Food Science, 35: 163-168.

Khouryieh, H., Herald, T., Aramouni, F. 2006. Quality and sensory properties of fresh egg noodles formulated with either total or partial replacement of egg substitutes. Journal of Food Science, 71: S433-S437.

Krkoskova, B., Mrazova, Z. 2005. Prophylactic components of buckwheat. Food Research International, 38: $561-568$.

Larmond, E. 1977. Laboratory Methods for Sensory Evaluation of Foods, Department of Agriculture Canada (Publication No. 1637), Ottawa, Canada.

Liu, Z., Ishikawa, W., Huang, X., Tomotake, H., Kayashita, J., Watanabe, H., Nakajoh, M., Kato, N. 2001. A buckwheat protein product suppresses 1,2-dimethylhydrazine-induced colon carcinogenesis in rats by reducing cell proliferation. Journal of Nutrition, 131: 1850-1853.

Lorenz, K. 1983. Protein fortification of cookies. Cereal Foods World, 28: 449-452.

Macrae, R.R., Robinson, K., Sadler, M.J. 1993. Encyclopedia of Food Science. Food Technology and Nutrition, vol. 4, pp. 345, Academic Press Harcourt Brace Jovanovich Publication, London, UK.

Mazza, G. 1989. Functional Foods. Technomic Publishing Co., Inc., Lancaster, PA, 334 pp., Pennsylvania, USA.

Ndife, J., Abdulraheem, L.O., Zakaria, U.M. 2011. Evaluation of the nutritional and sensory quality of functional breads produced from whole wheat flour and soya bean flour blended. African Journal of Food Sciences, 5: 466-472.

Pflaumer, P.F., Smith, E.D., Hudson, W.G. 1990. Cookies containing Psyllium. Plant Foods for Human Nutrition, 40: 115-121.

Pomeranz, Y., Robbins, G.S. 1972. Amino acid composition of buckwheat protein. Journal of Agriculture Food Chemistry, 20: 270-274.

Rani, A., Domont, G.B., Pedrosa, C., Ferrera, S.T. 2008. Functional properties of purified vicilins from cowpea (Vigna unguiculata) and pea (Pisum sativum) and cowpea protein isolate. Journal of Agricultural Food Chemistry, 51: 5792-5797.

Shahzad, H., Anjum, F.M., Butt, M.S., Khan, M.I., Asghar, A. 2006. Physical and sensoric attributes of flaxseed flour supplemented cookies. Turkish Journal of Biology, 30: 87-92.

Singh, B., Bajaj, M., Kaur, A., Sharma, S., Sidhu, J.S. 1993. Studies on the development of high protein biscuits from composite flours. Plant Foods for 
Human Nutrition, 43: 181-189.

Singh, D.P., Ahmad, S., Srivastava, P.K., Srivastava, A.K. 2005. Effects of soy flour incorporation on nutritional, sensory and textural characteristics of biscuits. Beverage and Food World, 32: 27-31.

Steadman, K.J., Burgoon, M.S., Lewis, B.A., Edwardson, S.E., Obendorf, R.L. 2001. Minerals, Phytic acid, tannin and rutin in buckwheat seed milling fractions. Journal of the Science of Food and Agriculture, 81: 1094-1100.

Steel, R.G.D., Torrie, J.H. 1997. Principles and Procedures of Statistics. In: A Biometrical Approach, $3^{\text {rd }}$ edition, McGraw Hill Pub. Co. Inc. New York, USA.
Tyagi, S.K., Manikantan, M.R., Harinder, O.S., Gurlen, K. 2007. Effect of mustard flour incorporation on nutritional, textural and organoleptic characteristics of biscuits. Journal of Food Engineering, 4: 10431050.

Wade, P. 1988. Biscuits, Cookies and Crackers. Principles of the Craft, vol. 1, Elesevier Applied Science, London, UK.

Wahab, S. 2001. Effect of Calcium Fortification on the Overall Quality of Wholewheat Flour Leavened and Unleavened Bread. Post Doctoral Thesis, College of Biosystem Engineering, Food Science, ZheJiang University, China. 